ISSN 0258-7122

Bangladesh J. Agril. Res. 38(3): 425-433, September 2013

\title{
EFFECT OF N, P, K, AND Mg APPLICATION ON YIELD AND FRUIT QUALITY OF MANDARIN (Citrus reticulata)
}

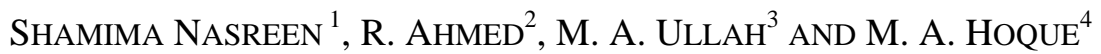

\begin{abstract}
The study was carried out at the farmer's field of Juri Upazilla, Maulavibazar District during 2008-2009, 2009-2010, and 2011-2012 to find out the proper combination of fertilizer nutrients that promotes better fruit yield and quality of mandarin (cv. Khashi Kamla). The treatments were Native nutrient i.e., control $\left(\mathrm{T}_{\mathrm{I}}\right), \quad \mathrm{N}_{150} \mathrm{P}_{50} \mathrm{~K}_{150} \mathrm{Mg}_{30} \quad\left(\mathrm{~T}_{2}\right), \quad \mathrm{N}_{200} \mathrm{P}_{75} \mathrm{~K}_{175} \mathrm{Mg}_{40} \quad\left(\mathrm{~T}_{3}\right), \quad \mathrm{N}_{250} \mathrm{P}_{100} \quad \mathrm{~K}_{200} \mathrm{Mg}_{50} \quad\left(\mathrm{~T}_{4}\right)$, $\mathrm{N}_{300} \mathrm{P}_{125} \mathrm{~K}_{225} \mathrm{Mg}_{60}\left(\mathrm{~T}_{5}\right)$, and $\mathrm{N}_{200} \mathrm{P}_{75} \mathrm{~K}_{175} \mathrm{Mg}_{0}\left(\mathrm{~T}_{6}\right) \mathrm{g} /$ plant/year. In addition, $20 \mathrm{~kg}$ cowdung/plant was used as blanket dose. Yield components, yield, and TSS content $(\%)$ of mandarin varied significantly due to variation of nutrients in all the test years. Fruit yield/plant was improved significantly with increase in NPK and $\mathrm{Mg}$ dose irrespective of years. Application of $\mathrm{Mg}$ in combination with NPK increased 17-157\% mean fruit yield over magnesium control. Significantly the highest yield and yield attributes were recorded under treatment $\mathrm{N}_{300} \mathrm{P}_{125} \mathrm{~K}_{225}$ $\mathrm{Mg}_{60} \mathrm{~g} /$ plant $\left(\mathrm{T}_{5}\right)$ along with $20 \mathrm{~kg}$ cowdung/plant in all the years. Total soluble sugar (\%) content was also maximum in trees receiving $\mathrm{N}_{300} \mathrm{P}_{125} \mathrm{~K}_{225} \mathrm{Mg}_{30}$ $\mathrm{g} /$ plant. The highest gross margin and marginal rate of return were achieved by the same treatment $\left(\mathrm{T}_{5}\right)$. The lowest fruit yield/plant was obtained from untreated control plot (native nutrient). Three years' study revealed that application of $\mathrm{N}_{300} \mathrm{P}_{125} \mathrm{~K}_{225} \mathrm{Mg}_{60}$ along with $20 \mathrm{~kg}$ cowdung/plant would be economically optimum for achieving higher yield and better fruit quality in mandarin grown under piedmont plain soil.
\end{abstract}

Keywords: Effects of $\mathrm{N}, \mathrm{P}, \mathrm{K}$, and $\mathrm{Mg}$, yield of mandarin, fruit quality of mandarin.

\section{Introduction}

Mandarin (Citrus reticulata) is a popular minor fruit of Bangladesh belonging to the species Citrus reticulata. It is tasty fruit having nutritional and medicinal value. It is rich in vitamin C (40 mg/100 g juice) and a good source of vitamin A and B. However, the productivity of mandarin in Bangladesh is very low compared to that in other countries of the world because the crop is exposed to biotic and abiotic stress, lack of high yielding varieties, and poor nutrient status of the soil as well as use of imbalanced fertilizers. Yield, however, can be increased considerably by adopting judicious nutrient management. The response of fertilization in improving the growth, yield, and quality of different citrus fruits is well recognized (Ghosh, 1990; Kumar et al., 1993; Ram et al., 1997 and

${ }^{1}$ Chief Scientific Officer, ${ }^{2}$ Scientific Officer, ${ }^{3}$ Principal Scientific Officer and ${ }^{4}$ Director, Horticulture Research Centre, Bangladesh Agricultural Research Institute (BARI), Gazipur 1701, Bangladesh. 
Shukla et al., 2000). Calvert (1970) has reported that significant role of N, P, Mg, $\mathrm{Zn}$, and B on growth, yield and quality of citrus fruit in India. Huchche et al. (1998) also reported that application of chemical fertilizers along with organic soil amendments increased mandarin yield in India. In Bangladesh, no systematic work on the nutritional requirement of mandarin in the hilly regions has been carried out. Therefore, the present study was undertaken to find out the proper combination of fertilizer nutrients in presence of organic manure for maximizing yield and better quality fruits of mandarin.

\section{Materials and Method}

The studies were conducted at the farmer's field of Juri Upazilla, Moilovibazar district during 2008-2009, 2009-2010, and 2011-2012. The soil of the experiment field is silty clay in texture belonging to the piedmont plain. Soil samples were collected from the experimental field from a depth of $0-20 \mathrm{~cm}$ prior to application of fertilizers in all the years. Results of soil analysis are presented in Table 1. Organic matter content of the soil was very low. The soil was acidic in nature. Total $\mathrm{N}$, exchangeable $\mathrm{K}, \mathrm{Ca}, \mathrm{Mg}$, and available $\mathrm{Zn}$ were found to be below the critical level.

Table 1. Chemical properties of the experimental soil (average of three years).

\begin{tabular}{c|c|c|c|c|c|c|c|c|c|c|c}
\hline $\mathrm{pH}$ & $\begin{array}{c}\mathrm{OM} \\
(\%)\end{array}$ & $\mathrm{Ca}$ & $\mathrm{Mg}$ & $\mathrm{K}$ & $\begin{array}{c}\text { Total } \\
\mathrm{N}(\%)\end{array}$ & $\mathrm{P}$ & $\mathrm{S}$ & $\mathrm{B}$ & $\mathrm{Zn}$ & $\mathrm{Fe}$ \\
\hline \multirow{2}{*}{4.32} & 0.74 & \multicolumn{3}{|c|}{ meq/100g soil } & \multirow{6}{*}{0.040} & \multicolumn{5}{|c}{$\mu \mathrm{g} / \mathrm{g}$} \\
\cline { 3 - 10 } & 1.5 & 0.60 & 0.12 & & 29 & 14 & 0.43 & 1.30 & 100 \\
\hline $\begin{array}{c}\text { Critical } \\
\text { Level }\end{array}$ & - & 2.0 & 0.8 & 0.20 & 0.12 & 14 & 14 & 0.2 & 2 & 10 \\
\hline
\end{tabular}

Six treatments consisted of $\mathrm{T}_{1}$ : native nutrient i.e., control, $\mathrm{T}_{2}: \mathrm{N}_{150} \mathrm{P}_{50} \mathrm{~K}_{150} \mathrm{Mg}_{30}, \quad \mathrm{~T}_{3}: \mathrm{N}_{200} \mathrm{P}_{75} \mathrm{~K}_{175} \mathrm{Mg}_{40}, \quad \mathrm{~T}_{4}: \mathrm{N}_{250} \mathrm{P}_{100} \mathrm{~K}_{200} \mathrm{Mg}_{50}, \quad \mathrm{~T}_{5}: \mathrm{N}_{300} \mathrm{P}_{125}$ $\mathrm{K}_{225} \mathrm{Mg}_{60}$, and $\mathrm{T}_{6}: \mathrm{N}_{200} \mathrm{P}_{75} \mathrm{~K}_{175} \mathrm{Mg}_{0} \mathrm{~g} /$ plant/year. In addition, $20 \mathrm{~kg}$ cowdung was used to each plant as blanket dose. The experiment was laid out in a randomized complete block design with three replications. Fertilizers $\mathrm{N}, \mathrm{P}, \mathrm{K}$, and $\mathrm{Mg}$ were applied to the field of 15 plants out of total 18 plants and doses were made constant after 10-year age of the plant as urea, triple super phosphate, muriate of potash, and magnesium sulphate, respectively. Full quantity of cowdung was applied to all plants during October. Nitrogen was applied in three splits during October, March, and May. Phosphorus, potassium, and magnesium were applied together after harvesting (during March). The test variety was Khashi Kamla (local). Intercultural operations were done as and when required. Mature fruits were harvested from $1^{\text {st }}$ week of October to end of October 2009, 2010, and 2011. Ten fruits of different sizes and shapes from each tree were randomly selected treatment-wise for data collection. All the collected data on different parameters were analyzed through MSTAT programme. The Least Significant Difference (LSD) test was used for mean separations of the studied parameters. 


\section{Results and Discussion}

Number of fruits/plant, fruit size, and individual fruit weight was influenced significantly by different nutrients in all the test years (Table 2). Plants grown with no fertilizer application (native nutrient) were found to have significantly lower number of fruits/plant than the plants grown with adequate nutrients. The plants treated with $\mathrm{N}_{300} \mathrm{P}_{125} \mathrm{~K}_{225} \mathrm{Mg}_{60} \mathrm{~g} /$ plant/year $\left(\mathrm{T}_{5}\right)$ produced the highest number of fruits/plant followed by that of $\mathrm{N}_{250} \mathrm{P}_{100} \mathrm{~K}_{200} \mathrm{Mg}_{50}$ treatment $\left(\mathrm{T}_{4}\right)$ irrespective of years. Monga et al. (2004) also reported that application of NPK fertilizer increased the number of fruits/plant of Kinnow mandarin. Significant increase in length of mandarin was also recorded with $\mathrm{N}_{300} \mathrm{P}_{125} \mathrm{~K}_{225} \mathrm{Mg}_{60}$ treatment $\left(\mathrm{T}_{5}\right)$ and it was statistically identical with $\mathrm{N}_{250} \mathrm{P}_{100} \mathrm{~K}_{200} \mathrm{Mg}_{50}$ treatment $\left(\mathrm{T}_{4}\right)$. The smallest fruit was obtained from the control treatment $\left(\mathrm{T}_{\mathrm{I}}\right)$. Diameter of mandarin showed almost similar trend or response to length. The weight of individual fruit varied considerably and increased significantly with different treatments. Maximum fruit weight was recorded with application of $\mathrm{N}_{300} \mathrm{P}_{125} \mathrm{~K}_{225} \mathrm{Mg}_{60} \mathrm{~g} /$ plant and it was significantly superior to all other treatment combinations in all the years. The control treatment receiving no fertilizer produced the lowest individual fruit weight.

Fruit yield/plant was significantly influenced by the application of different nutrients in all the years (Fig. 1). Fruit yield increased significantly with the increasing rate of NPK and Mg in all the test years. In the present study, fertilizer application increased mean yield from 32.77 to $104.19 \mathrm{~kg} / \mathrm{plant}$ in 2008-2009, 27.36 to $94.96 \mathrm{~kg} / \mathrm{plant}$ in 2009-2010, and 23.39 to $84.07 \mathrm{~kg} / \mathrm{plant}$ in 2011-2012. Annual variation in fruit yield of mandarin/plant was probably due to climatic factors in different seasons. The highest fruit yield/plant was obtained from the treatment $\mathrm{N}_{300} \mathrm{P}_{125} \mathrm{~K}_{225} \mathrm{Mg}_{60} \mathrm{~g} /$ plant $\left(\mathrm{T}_{5}\right)$ and it was significantly higher than all other treatments. The yield benefit for $\mathrm{T}_{5}$ treatment was $218 \%$ in 2008-2009, 247\% in 2009-2010, and 259\% in 2011- 2012 over control treatment. Again it was found that application of magnesium increased $17-157 \%$ mean fruit yield over magnesium control. There was a large increase in yield owing to different nutrient applications indicating that soil was originally deficient in nutrients (Table 1). Application of chemical fertilizers perhaps helped in maintaining soil fertility and offered favourable response, which was reflected by higher yield. Moreover, supply of sufficient amount of nutrients necessary for better growth and plant development which resulted in higher yield due to higher fruit set and weight. Huchche el al. (1998) reported that application of chemical fertilizers along with organic soil amendments enriched the soil fertility leading to higher yield. Monga el al. (2004) also reported that application of NPK fertilizer increased fruit yield of Kinnow mandarin significantly over control in India. Plants grown without fertilizer (native nutrient) had the lowest fruit yield/plant irrespective of years. 
Table 2. Effect of NPK and Mg fertilizers on the number of fruits/plant, fruit size and individual fruit weight of mandarin during 2008-2009, 2009-2010, and 2011-2012.

\begin{tabular}{|c|c|c|c|c|c|c|c|c|c|c|c|c|}
\hline \multirow{3}{*}{$\begin{array}{c}\text { Treat- } \\
\text { ment }\end{array}$} & \multirow{2}{*}{\multicolumn{3}{|c|}{ Fruits/plant (no.) }} & \multicolumn{6}{|c|}{ Fruit size $(\mathrm{cm})$} & \multirow{2}{*}{\multicolumn{3}{|c|}{$\begin{array}{l}\text { Individual fruit } \\
\qquad \mathrm{wt}(\mathrm{g})\end{array}$}} \\
\hline & & & & \multicolumn{3}{|c|}{ Length } & \multicolumn{3}{|c|}{ Diameter } & & & \\
\hline & 2008-09 & $2009-10$ & $2011-12$ & 2008-09 & $2009-10$ & 2011-12 & 2008-09 & $2009-10$ & $2011-12$ & 2008-09 & $2009-10$ & 2011-12 \\
\hline $\mathrm{T}_{1}$ & 316 & 262 & 268 & 4.87 & 4.90 & 4.35 & 5.48 & 5.20 & 4.68 & 109.24 & 107.57 & 90.28 \\
\hline $\mathrm{T}_{2}$ & 350 & 348 & 308 & 5.67 & 5.46 & 5.35 & 6.13 & 5.70 & 5.77 & 134.80 & 133.03 & 130.00 \\
\hline $\mathrm{T}_{3}$ & 433 & 425 & 405 & 5.98 & 5.93 & 5.45 & 6.35 & 6.05 & 5.94 & 152.02 & 152.54 & 146.53 \\
\hline $\mathrm{T} 4$ & 483 & 475 & 426 & 6.20 & 6.02 & 5.57 & 6.62 & 6.17 & 6.09 & 175.89 & 170.39 & 162.24 \\
\hline $\mathrm{T}_{5}$ & 532 & 518 & 485 & 6.30 & 6.17 & 5.70 & 6.87 & 6.42 & 6.33 & 194.71 & 194.38 & 178.40 \\
\hline $\mathrm{T}_{6}$ & 320 & 317 & 290 & 5.40 & 5.15 & 4.95 & 6.07 & 5.56 & 5.12 & 130.92 & 124.87 & 120.54 \\
\hline $\operatorname{LSD}(0.0$ & 05) 87 & 58 & 21 & 0.78 & 0.30 & 0.32 & 0.48 & 0.36 & 0.38 & 15.67 & 14.62 & 16.08 \\
\hline $\mathrm{CV}(\%)$ & 11.8 & 9.3 & 10.0 & 7.5 & 4.8 & 6.7 & 4.2 & 5.6 & 7.0 & 5.6 & 5.5 & 9.8 \\
\hline
\end{tabular}

$\mathrm{T}_{1}=$ Native nutrient (control), $\mathrm{T}_{2}=\mathrm{N}_{150} \mathrm{P}_{50} \mathrm{~K}_{150} \mathrm{Mg}_{30}, \mathrm{~T}_{3}=\mathrm{N}_{200} \mathrm{P}_{75} \mathrm{~K}_{175} \mathrm{Mg}_{40}, \mathrm{~T}_{4}=\mathrm{N}_{250} \mathrm{P}_{100} \mathrm{~K}_{200} \mathrm{Mg}_{50}, \mathrm{~T}_{5}=\mathrm{N}_{300} \mathrm{P}_{125} \mathrm{~K}_{225} \mathrm{Mg}_{60}$, and $\mathrm{T}_{6}=\mathrm{N}_{200} \mathrm{P}_{75} \mathrm{~K}_{175} \mathrm{Mg}_{0} \mathrm{~g} /$ plant/year 
Table 3. Effect of NPK and Mg on weight of pulp, number of segments and total soluble sugar(TSS) content of mandarin during 2008-2009, 2009-2010, and 2011-2012.

\begin{tabular}{|c|c|c|c|c|c|c|c|c|c|}
\hline Treatment & \multicolumn{3}{|r|}{ weight } & \multicolumn{3}{|c|}{ Segments (no.) } & \multicolumn{3}{|c|}{ Total soluble sugar (\%) } \\
\hline $\mathrm{T}_{1}$ & 24.78 & 19.25 & 16.25 & 8.46 & 9.10 & 9.02 & 7.70 & 8.53 & 8.63 \\
\hline $\mathrm{T}_{2}$ & 29.95 & 26.51 & 23.51 & 9.33 & 9.46 & 9.49 & 8.20 & 8.88 & 9.45 \\
\hline $\mathrm{T}_{3}$ & 36.42 & 31.22 & 28.22 & 10.00 & 9.80 & 9.81 & 8.60 & 9.06 & 9.62 \\
\hline $\mathrm{T}_{5}$ & 47.00 & 39.40 & 36.38 & 11.33 & 10.37 & 10.44 & 9.70 & 9.51 & 10.40 \\
\hline $\mathrm{T}_{6}$ & 27.03 & 23.16 & 20.15 & 9.33 & 9.40 & 9.44 & 8.20 & 8.80 & 9.07 \\
\hline LSD (0.05) & 4.51 & 2.35 & 2.31 & 0.72 & 0.24 & 0.26 & 0.41 & 0.20 & 0.30 \\
\hline $\mathrm{CV}(\%)$ & 7.3 & 6.4 & 5.5 & 4.1 & 4.4 & 6.0 & 2.7 & 3.9 & 5.3 \\
\hline
\end{tabular}

$\mathrm{T}_{1}=$ Native nutrient (control), $\mathrm{T}_{2}=\mathrm{N}_{150} \mathrm{P}_{50} \mathrm{~K}_{150} \mathrm{Mg}_{30}, \mathrm{~T}_{3}=\mathrm{N}_{200} \mathrm{P}_{75} \mathrm{~K}_{175} \mathrm{Mg}_{40}, \mathrm{~T}_{4}=\mathrm{N}_{250} \mathrm{P}_{100} \mathrm{~K}_{200} \mathrm{Mg}_{50}, \mathrm{~T}_{5}=\mathrm{N}_{300} \mathrm{P}_{125} \mathrm{~K}_{225} \mathrm{Mg}_{60}$, and $\mathrm{T}_{6}=\mathrm{N}_{200} \mathrm{P}_{75} \mathrm{~K}_{175} \mathrm{Mg}_{0} \mathrm{~g} /$ plant/year 


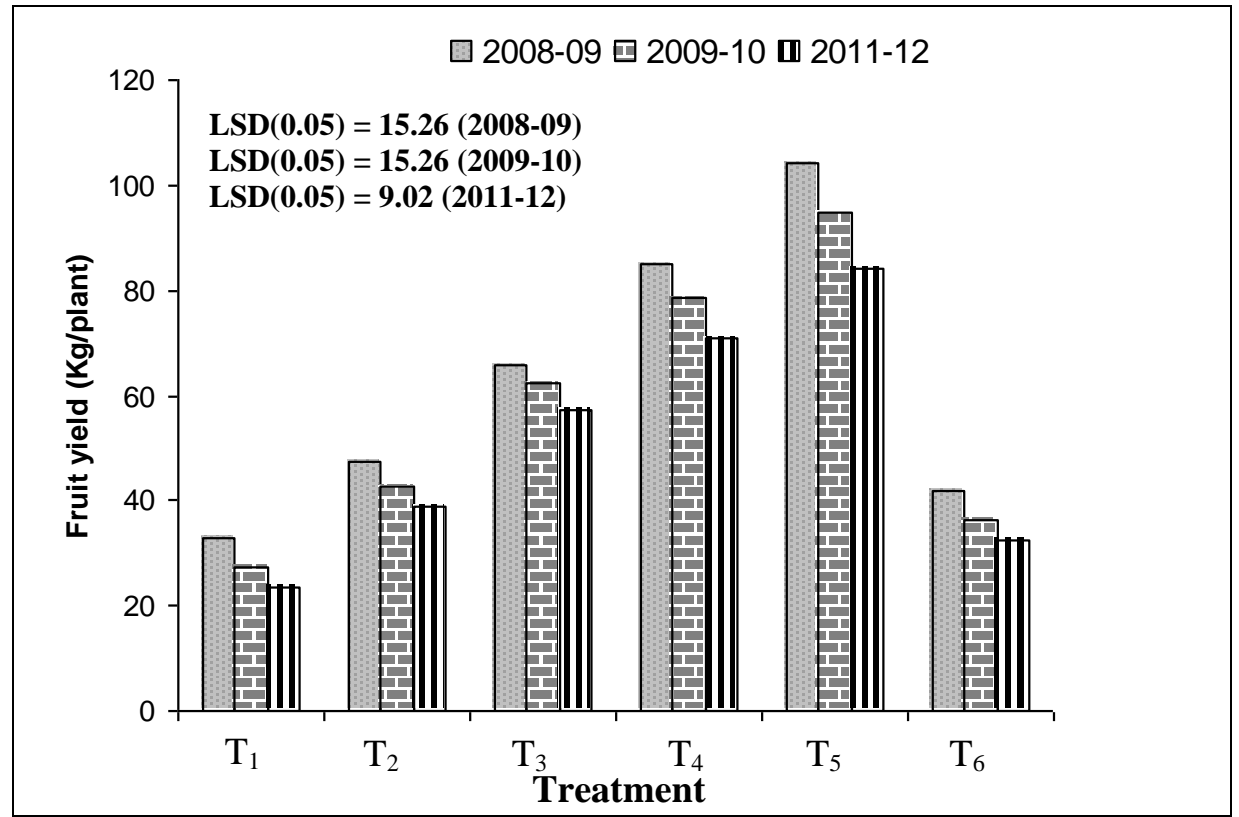

Fig. 1. Effect of NPK and Mg fertilizer on fruit yield of mandarin in 2008-2009, 2009-2010, and 2011-2012.

Where, $\mathrm{T}_{1}=$ Native nutrient, $\mathrm{T}_{2}=\mathrm{N}_{150} \mathrm{P}_{50} \mathrm{~K}_{150} \mathrm{Mg}_{30}, \mathrm{~T}_{3}=\mathrm{N}_{200} \mathrm{P}_{75} \mathrm{~K}_{175} \mathrm{Mg}_{40}$, $\mathrm{T}_{4}=\mathrm{N}_{250} \mathrm{P}_{100} \mathrm{~K}_{200} \mathrm{Mg}_{50}, \mathrm{~T}_{5}=\mathrm{N}_{300} \mathrm{P}_{125} \mathrm{~K}_{225} \mathrm{Mg}_{60}$ and $\mathrm{T}_{6}=\mathrm{N}_{200} \mathrm{P}_{75} \mathrm{~K}_{175} \mathrm{Mg}_{0} \mathrm{~g} /$ plant/year

The effect of different nutrients (NPK and $\mathrm{Mg}$ ) was also significant on weight of pulp, number of segment, and TSS content of mandarin in all the test years (Table 3). Maximum weight of pulp and number of segments were recorded with application of $\mathrm{N}_{300} \mathrm{P}_{125} \mathrm{~K}_{225} \mathrm{Mg}_{60} \mathrm{~g} /$ plant treatments, while the minimum pulp weight and number of segments were recorded in untreated plants (control). Total soluble sugar (TSS) content was maximum in plant receiving $\begin{array}{lllll}\mathrm{N}_{300} & \mathrm{P}_{125} & \mathrm{~K}_{225} & \mathrm{Mg}_{60} & \mathrm{~g} / \mathrm{plant} \text { and it was significantly superior to all other }\end{array}$ treatments. Plants grown without nutrients (native nutrient) gave minimum TSS content irrespective of years.

\section{Economic evaluation}

Gross return was calculated from the price of mandarin. Variable cost was calculated from the costs involved for fertilizer used for the experimental treatments. The partial budget analysis of fertilizer showed that the mean gross return from the control plot was Tk.1516/plant and the application of fertilizer increased the gross return up to Tk.3947/plant. The gross margin ranged from Tk. 1311 to Tk. 3801/plant in 2008-2009, Tk. 1094 to Tk. 3431/plant in 20092010 and Tk. 2144toTk. 3524/plant in 2011-2012.The maximum mean gross 
Table 4. Partial budget and dominance analysis for different fertilizer response data of mandarin during 2008-2009, 2009-2010 and 2011-2012.

\begin{tabular}{|c|c|c|c|c|c|c|c|c|c|c|c|c|}
\hline \multirow{2}{*}{ Treatment } & \multicolumn{3}{|c|}{$\begin{array}{r}\text { Gross return } \\
\text { (Tk./plant) }\end{array}$} & \multicolumn{3}{|c|}{$\begin{array}{l}\text { Variable cost } \\
\text { (Tk./ plant) }\end{array}$} & \multicolumn{3}{|c|}{$\begin{array}{l}\text { Gross margin } \\
\text { (Tk./plant) }\end{array}$} & \multicolumn{3}{|c|}{ Remarks } \\
\hline & 2008-09 & 2009-10 & 2011-12 & 2008-09 & $\begin{array}{r}2009- \\
10\end{array}$ & 2011-12 & 2008-09 & $2009-10$ & 2011-12 & 2008-09 & $2009-10$ & 2011-12 \\
\hline $\mathrm{T}_{1}$ & 1311 & 1094 & 2144 & 0 & 0 & 0 & 1311 & 1094 & 2144 & $\mathrm{CU}$ & $\mathrm{CU}$ & $\mathrm{CU}$ \\
\hline $\mathrm{T}_{2}$ & 1880 & 1701 & 2466 & 184 & 184 & 178 & 1696 & 1517 & 2268 & $\mathrm{CD}$ & $\mathrm{CD}$ & $\mathrm{CD}$ \\
\hline $\mathrm{T}_{3}$ & 2635 & 2500 & 3240 & 245 & 245 & 237 & 2390 & 2255 & 3003 & $\mathrm{CU}$ & $\mathrm{CU}$ & $\mathrm{CU}$ \\
\hline $\mathrm{T}_{4}$ & 3396 & 3144 & 3408 & 306 & 306 & 297 & 3090 & 2838 & 3111 & $\mathrm{CU}$ & $\mathrm{CU}$ & $\mathrm{CU}$ \\
\hline $\mathrm{T}_{5}$ & 4168 & 3794 & 3880 & 367 & 367 & 356 & 3801 & 3431 & 3524 & $\mathrm{CU}$ & $\mathrm{CU}$ & $\mathrm{CU}$ \\
\hline $\mathrm{T}_{6}$ & 1670 & 1444 & 2320 & 34 & 34 & 27 & 1636 & 1410 & 2293 & $\mathrm{CU}$ & $\mathrm{CU}$ & $\mathrm{CU}$ \\
\hline
\end{tabular}

$\mathrm{T}_{1=}$ Native nutrient (control), $\mathrm{T}_{2}=\mathrm{N}_{150} \mathrm{P}_{50} \mathrm{~K}_{150} \mathrm{Mg}_{30}, \mathrm{~T}_{3}=\mathrm{N}_{200} \mathrm{P}_{75} \mathrm{~K}_{175} \mathrm{Mg}_{40}, \mathrm{~T}_{4}=\mathrm{N}_{250} \mathrm{P}_{100} \mathrm{~K}_{200} \mathrm{Mg}_{50}, \mathrm{~T}_{5}=\mathrm{N}_{300} \mathrm{P}_{125} \mathrm{~K}_{225} \mathrm{Mg}_{60}$ and $\mathrm{T}_{6}=\mathrm{N}_{200} \mathrm{P}_{75} \mathrm{~K}_{175} \mathrm{Mg}_{0} \mathrm{~g} /$ plant/year, $\mathrm{CU}=$ Cost undominated and $\mathrm{CD}=$ Cost dominated. 
Table 5. Marginal analysis of undominated fertilizers response data of mandarin during 2008-2009, 2009-2010, and 2011-2012.

\begin{tabular}{|c|c|c|c|c|c|c|c|c|c|c|c|c|c|c|c|}
\hline \multirow{2}{*}{$\begin{array}{l}\text { Treat- } \\
\text { ments }\end{array}$} & \multicolumn{3}{|c|}{$\begin{array}{l}\text { Gross margin } \\
\text { (Tk./plant) }\end{array}$} & \multicolumn{3}{|c|}{$\begin{array}{l}\text { Variable cost } \\
\text { (Tk./plant) }\end{array}$} & \multicolumn{3}{|c|}{$\begin{array}{l}\text { Marginal } \\
\text { increase }{ }_{\mathrm{i}} \mathrm{n} \text { gross } \\
\text { martin (Tk/plant) }\end{array}$} & \multicolumn{3}{|c|}{$\begin{array}{l}\text { Marginal increase } \\
\text { in variable cost } \\
\text { (Tk./ha) }\end{array}$} & \multicolumn{3}{|c|}{$\begin{array}{c}\text { Marginal rate of } \\
\text { return }(\%)\end{array}$} \\
\hline & $\begin{array}{c}2008- \\
09\end{array}$ & $\begin{array}{c}2009- \\
10\end{array}$ & $\begin{array}{c}2011- \\
12\end{array}$ & $\begin{array}{c}2008- \\
09\end{array}$ & $\begin{array}{c}2009- \\
10\end{array}$ & $\begin{array}{c}2011- \\
12\end{array}$ & $\begin{array}{c}2008- \\
09\end{array}$ & $\begin{array}{r}2009 \\
10\end{array}$ & $\begin{array}{c}2011- \\
12\end{array}$ & $\begin{array}{c}2008 \\
09\end{array}$ & $\begin{array}{c}2009 \\
-10\end{array}$ & $\begin{array}{c}2011- \\
12\end{array}$ & $\begin{array}{c}2008- \\
09\end{array}$ & $\begin{array}{c}2009- \\
10\end{array}$ & $\begin{array}{c}2011- \\
12\end{array}$ \\
\hline $\mathrm{T}_{5}$ & 3801 & 3431 & 3524 & 367 & 367 & 356 & 711 & 593 & 413 & 61 & 61 & 59 & 1166 & 972 & 700 \\
\hline $\mathrm{T}_{4}$ & 3090 & 2838 & 3111 & 306 & 306 & 297 & 700 & 583 & 108 & 61 & 61 & 60 & 1148 & 958 & 180 \\
\hline $\mathrm{T}_{3}$ & 2390 & 2255 & 3003 & 245 & 245 & 237 & 754 & 845 & 710 & 211 & 211 & 210 & 357 & 400 & 338 \\
\hline $\mathrm{T}_{6}$ & 1636 & 1410 & 2293 & 34 & 34 & 27 & 325 & 316 & 149 & 34 & 34 & 27 & 956 & 929 & 552 \\
\hline $\mathrm{T}_{1}$ & 1311 & 1094 & 2144 & 0 & 0 & 0 & - & - & - & - & - & - & - & - & - \\
\hline
\end{tabular}

$\mathrm{T}_{1}=$ Native nutrient (control), $\mathrm{T}_{2}=\mathrm{N}_{150} \mathrm{P}_{50} \mathrm{~K}_{150} \mathrm{Mg}_{30}, \mathrm{~T}_{3}=\mathrm{N}_{200} \mathrm{P}_{75} \mathrm{~K}_{175} \mathrm{Mg}_{40}, \mathrm{~T}_{4}=\mathrm{N}_{250} \mathrm{P}_{100} \mathrm{~K}_{200} \mathrm{Mg}_{50}, \mathrm{~T}_{5}=\mathrm{N}_{300} \mathrm{P}_{125} \mathrm{~K}_{225} \mathrm{Mg}_{60}$ and $\mathrm{T}_{6}=\mathrm{N}_{200} \mathrm{P}_{75} \mathrm{~K}_{175} \mathrm{Mg}_{0} \mathrm{~g} /$ plant/year. 
margin of Tk. $3585 /$ plant was achieved with the treatment $\mathrm{N}_{300} \mathrm{P}_{125} \mathrm{~K}_{225} \mathrm{Mg}_{60}$ (Table 4). Dominance analysis shows that the treatment $\mathrm{N}_{150} \mathrm{P}_{50} \mathrm{~K}_{150} \mathrm{Mg}_{30}\left(\mathrm{~T}_{2}\right)$ is cost dominated irrespective of years. Marginal analysis (Table 5) showed that the highest marginal rate of return (MRR) of $1166 \%$ in $2008-2009$, $972 \%$ in 2009 2010 and $700 \%$ in 2011-2012 was obtained from the $\mathrm{N}_{300} \mathrm{P}_{125} \mathrm{~K}_{225} \mathrm{Mg}_{60} \mathrm{~g} / \mathrm{plant}$ treatment $\left(\mathrm{T}_{5}\right)$ followed by that of $\mathrm{N}_{250} \mathrm{P}_{100} \mathrm{~K}_{200} \mathrm{Mg}_{50} \mathrm{~g}$ /plant $1148 \%$ in 2008-2009 and $958 \%$ in 2009-2010. Hence, application of $\mathrm{N}_{300} \mathrm{P}_{125} \mathrm{~K}_{225} \mathrm{Mg}_{60} \mathrm{~g} / \mathrm{plant}$ in presence of $20 \mathrm{~kg}$ cowdung/plant would be economically acceptable for the mandarin production in the hilly region of Piedmont plain soil.

\section{Conclusion}

Three years' study revealed that application of fertilizers at the rate of $\mathrm{N}_{300} \mathrm{P}_{125} \mathrm{~K}_{225} \quad \mathrm{Mg}_{60}$ g/plant along with $20 \mathrm{~kg}$ cowdung/plant would be economically optimum for achieving higher yield and better fruit quality of mandarin in piedmont plain soil of Juri Upazilla, Moluvibazar.

\section{Acknowledgement}

The piece of research was part of the project 'Orange Development Project' funded by the Government of the Peoples Republic of Bangladesh.

\section{References}

Calver, D.V. 1970. Response of oranges to varying rates of nitrogen, potassium and magnesium. Proc. Fle. Hort. Soc. 3: 10-15.

Huchche, A. D., M. S. Landaniya, Lallan Ram, R. R. Kohli and A. K. Srivastava. 1998. Effect of nitrogenous fertilizers and farm yard manure on yield, quality, and shelf life of Nagpur Mandarin. Indian J. Hort. 55(2): 108-112.

Monga, P. K., V. K. Vij and J. N. Sharma. 2004. Effect of N, P, and K on the yield and fruit quality of Kinnow mandarin. Indian J. Hort. 61(4): 302-304.

Ghose, S. N. 1990. Nutritional requirement of sweet orange (Citrus sinensis) cv. Mosambi. Haryana J. Hort. Sci. 19: 39-44.

Kumar. R., V. P. Ahalawat and B.S. Daulata. 1993. Growth, yield and quality attributes of Kinnow (C. reticulate) as affected by nitrogen and phosphorus application. Haryana J. Hort. Sci. 22: 8-13.

Ram, L.; R. R. Kohli; A. K. Srivastava; A. D. Huchche and H. C. Das. 1997. Nutritional requirement of Nagpur Mandarin (C. reticulata) grown on vertisol in central region. Indian J. Hort. 54: 91-97.

Shukla, A. K., A. M. Goswami, S. K. Saxena, R. R. Sharma and Pratap Bhanu. 2000. Effect of nitrogen and phosphorus on growth and yield of Kinnow under high density planting. Ann. Agric. Res. 2: 540-543. 